\title{
Front Matter: Volume 10336
}

, "Front Matter: Volume 10336," Proc. SPIE 10336, Saratov Fall Meeting 2016: Optical Technologies in Biophysics and Medicine XVIII, 1033601 (13 April 2017); doi: 10.1117/12.2276079 and Biophotonics, 2016, Saratov, Russian Federation 


\title{
PROGRESS IN BIOMEDICAL OPTICS AND IMAGING
}

\section{Saratov Fall Meeting 2016}

\section{Optical Technologies in Biophysics and Medicine XVIII}

\author{
Elina A. Genina \\ Valery V. Tuchin
}

Editors

\section{7-30 September 2016 \\ Saratov, Russian Federation}

\section{Sponsored by}

Russian Foundation for Basic Research (Russian Federation) • Russian Academy of Sciences (Russian Federation) • The Optical Society • IEEE - The Photonics Society • Russian Technology Platform "The Medicine of the Future" (Russian Federation) • Russian Technology Platform "Photonics" (Russian Federation) • European Technology Platform "Photonics21" (Russian Federation) • EPIC - European Photonics Industry Consortium • COST Action, BM1205 (European Cooperation in Science and Technology)

Published by

SPIE 
The papers in this volume were part of the technical conference cited on the cover and title page. Papers were selected and subject to review by the editors and conference program committee. Some conference presentations may not be available for publication. Additional papers and presentation recordings may be available online in the SPIE Digital Library at SPIEDigitallibrary.org.

The papers reflect the work and thoughts of the authors and are published herein as submitted. The publisher is not responsible for the validity of the information or for any outcomes resulting from reliance thereon.

Please use the following format to cite material from these proceedings:

Author(s), "Title of Paper," in Saratov Fall Meeting 2016: Optical Technologies in Biophysics and Medicine XVIII, edited by Elina A. Genina, Valery V. Tuchin, Proceedings of SPIE Vol. 10336 (SPIE, Bellingham, WA, 2017) Seven-digit Article CID Number.

ISSN: 1605-7422

ISSN: 2410-9045 (electronic)

ISBN: 9781510611177

ISBN: 9781510611184 (electronic)

Published by

SPIE

P.O. Box 10, Bellingham, Washington 98227-0010 USA

Telephone +1 3606763290 (Pacific Time) · Fax +1 3606471445

SPIE.org

Copyright @ 2017 , Society of Photo-Optical Instrumentation Engineers.

Copying of material in this book for internal or personal use, or for the internal or personal use of specific clients, beyond the fair use provisions granted by the U.S. Copyright Law is authorized by SPIE subject to payment of copying fees. The Transactional Reporting Service base fee for this volume is $\$ 18.00$ per article (or portion thereof), which should be paid directly to the Copyright Clearance Center (CCC), 222 Rosewood Drive, Danvers, MA 01923. Payment may also be made electronically through CCC Online at copyright.com. Other copying for republication, resale, advertising or promotion, or any form of systematic or multiple reproduction of any material in this book is prohibited except with permission in writing from the publisher. The CCC fee code is 1605 $7422 / 17 / \$ 18.00$.

Printed in the United States of America.

Publication of record for individual papers is online in the SPIE Digital Library.

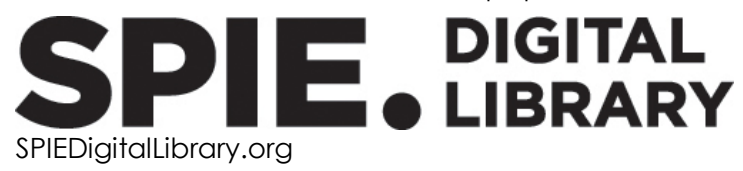

Paper Numbering: Proceedings of SPIE follow an e-First publication model. A unique citation identifier (CID) number is assigned to each article at the time of publication. Utilization of CIDs allows articles to be fully citable as soon as they are published online, and connects the same identifier to all online and print versions of the publication. SPIE uses a seven-digit CID article numbering system structured as follows:

- The first five digits correspond to the SPIE volume number.

- The last two digits indicate publication order within the volume using a Base 36 numbering system employing both numerals and letters. These two-number sets start with 00, 01, 02, 03, 04, 05, 06, 07, 08, 09, OA, OB ... OZ, followed by 10-1Z, 20-2Z, etc. The CID Number appears on each page of the manuscript. 


\title{
Contents
}

\author{
vii Authors \\ ix Conference Committee \\ xi Introduction \\ $\mathrm{xv} \quad$ Organizers
}

INVITED PAPER SESSION

1033602 Synchronous fluorescence spectroscopy of colon neoplasia (Invited Paper) [10336-92]

BEST STUDENT PAPER AWARD WINNERS

1033603 The depending of Langmuir monolayers of quantum dots and fatty acid mixture properties from their components ration (Best Student Paper Award) [10336-87]

1033604 Non-invasive control of influence of polyethylene glycol on transport function of fluorescent colored liposomal nanoparticles (Best Student Paper Award) [10336-90]

\section{OPTICAL TECHNOLOGIES IN BIOPHYSICS AND MEDICINE}

1033605 Optical tweezers for measuring the interaction of the two single red blood cells in flow condition [10336-1 18]

1033606 Gamma globulins-induced interaction between two red blood cells: forces measurement with optical tweezers [10336-119]

1033607 Evaluation of blood microcirculation parameters by combined use of laser Doppler flowmetry and videocapillaroscopy methods [10336-47]

1033608 The influence of local pressure on evaluation parameters of skin blood perfusion and fluorescence [10336-49]

1033609 The application of digital image analysis for blood typing: the comparison of anti-A and anti-B monoclonal antibodies activity with standard hemagglutinating sera [10336-62]

10336 OA The counting of native blood cells by digital microscopy [10336-68]

$10336 \mathrm{OB}$ In vitro destruction of anterior human lens capsule by submicrosecond pulses of Yb,Er:Glass laser [10336-72] 
10336 OC Temperature dynamics of soft tissues during diode laser cutting by different types of fiber opto-thermal converters [10336-73]

10336 OD Using of methods of speckle optics for Chlamydia trachomatis typing [10336-116]

10336 OE Optical methods for the evaluation of film-forming ability of UPEC on the surface of medical devices [10336-18]

10336 OF Influence of red laser irradiation and photosensitizers Photoditazine and Dimegin on the growth of methicillin-resistant strain of Staphylococcus aureus [10336-21]

10336 OG Different reaction of the core histones H2A and H2B to red laser irradiation [10336-42]

\section{SPECTROSCOPY AND MOLECULAR MODELING}

$10336 \mathrm{OH}$ Interaction of fullerenol with metals: the research by laser correlation spectroscopy [10336-96]

10336 Ol FT-IR and DFT study of lemon peel [10336-54]

$103360 \mathrm{~J}$ Studying the mechanism of tissue optical clearing using the method of molecular dynamics [10336-56]

10336 OK Diamond-like nanoparticles influence on flavonoids transport: molecular modelling [10336-24]

\section{NANOBIOPHOTONICS AND LOW-DIMENSIONAL STRUCTURES}

10336 OL Cell culture surfaces with immobilized gold nanostars: a new approach for laser-induced plasmonic cell optoporation [10336-114]

10336 OM Synthesis of SERS-nanotags and their investigation inside photonic crystal fiber [10336-79]

10336 ON The optical properties of quantum dots integrated in a hollow core photon crystal fiber [10336-89]

1033600 Synthesis of high luminescent carbon nanoparticles [10336-77]

10336 OP Bovine serum albumin nanoparticles loaded with Photosens photosensitizer for effective photodynamic therapy [10336-78]

$103360 Q$ The assesment of effectiveness of plasmonic resonance photothermal therapy in tumor-bearing rats after multiple intravenous administration of gold nanorods [10336-59]

10336 OR Fabrication, size control and functionalization of silver nanoparticles by pulsed laser ablation synthesis in liquid [10336-32]

10336 OS The application of laser pointers for demonstration experiments in nanotechnology lessons at secondary school level [10336-80] 
10336 OT Modification of the internal surface of photonic crystal fibers with Ag and Au nanoparticles for application as sensor elements [10336-85]

MICROSCOPIC AND LOW-COHERENCE METHODS IN BIOMEDICAL AND NON-BIOMEDICAL APPLICATIONS

10336 OU Stiffness of RBC optical confinement affected by optical clearing [10336-38]

10336 OV Fluorescent angiography of chicken embryo and photobleaching velocimetry [10336-41]

INTERNET BIOPHOTONICS

10336 OW Adaptive $\mu$ PIV for visualization of capillary network microcirculation using Niblack local binarization [10336-69]

10336 OX Investigation of flavonoid influence on peroxidation processes intensity in the blood [10336-60]

10336 OY Specific features of movement of the photon density normalized maximum in highly scattering media with tissue-like optical properties [10336-86]

$103360 Z$ Monte-Carlo simulation of OCT structural images of human skin using experimental B-scans and voxel based approach to optical properties distribution [10336-94]

$1033610 \quad$ Laser speckle contrast imaging of cerebral blood flow of newborn mice at optical clearing [10336-61]

1033611 Tissue sensing by structured illumination in optical diffuse reflectometry [10336-95] BIOMEDICAL SPECTROSCOPY

1033612 Optical properties of human nails in THz frequency range [10336-67]

1033613 Detection of rhodamine 6G in blood and urine using combination of surface-enhanced Raman spectroscopy and liquid-liquid extraction [10336-75]

1033614 Influence of excitation power density on temperature dependencies of $\mathrm{NaYF}_{4}: \mathrm{Yb}_{\mathrm{B}} \mathrm{Er}$ nanoparticles luminescence spectra [10336-82]

1033615 Synthesis and investigation of rosin nanoparticles [10336-84]

1033616 Fabrication of tissue phantoms with embedded CdSe/ZnS quantum dots, gold and upconversion nanoparticles [10336-91] 
ADVANCED POLARIZATION TECHNOLOGIES IN BIOMEDICINE AND MATERIAL SCIENCE

1033617 Comparative characteristics of the information content of biochemical and electrical parameters of biotissues in the modeling of the induced development of precancerous abnormalities of the gastrointestinal tract in rats [10336-58]

1033618 Tissue structure characterization of biotissue phantom by use of the speckle-correlometric technique [10336-34]

1033619 Dielectric function of TiO2 nanoparticles under laser pumping [10336-31]

10336 1A Dynamic light scattering probes of structure instabilities in foamed substances [10336-40]

10336 1B Scenarios of the disorder increase in the polarization states of partial contributions to the multiple scattered light fields [10336-71]

10336 1C Statistical properties of speckled fluorescence in dye-doped coarse-grained random media [10336-2] 
Nechaeva, Olga $\vee .$, OE

Nepomnyashchaya, Elina, $\mathrm{OH}$

Novikova, Anastasia S., 16

Novoselova, A. V., Ol

Packirisamy, Gopinath, OP

Pantyukov, A. V., 18

Penkov, Nikolay, 02

Petrov, D. A., OZ

Petrova, Polina S., 00

Pidenko, Pavel S., ON, OT

Pidenko, Sergei A., ON

Plastun, Inna L., OK, OX

Plekhanov, V. I., 11

Pleshakova, Ekaterina $\vee ., 17$

Polukonova, N. V., OX

Ponomaryov, G. V., OF

Postnov, Dmitry E., OG, OV

Potlov, A. Yu., OY, OZ

Priezzhev, Alexander, 05, 06

Prilepskii, Artur, OL

Proskurin, S. G., OY, OZ

Pylaev, Timofey, OL

Rusanova, Tatiana Yu., OT

Sagatova, Madina M., 10

Saltykov, Yury V., OD

Samoilov, L. V., IA

Savchenko, Ekaterina, $\mathrm{OH}$

Savenko, Olga A., OT, 14, 16

Sedykh, Egor A., 12

Semenov, Alexei, 05, 06

Semyachkina-Glushkovskaya, Oxana V., 02, 10,

17

Semyashkina, Yulia $\vee ., 0 C$

Sergeev, Andrey N., OB

Sergeeva, E. A., 11

Seryogina, E. S., 08

Shagautdinova, I. T., Ol, OJ

Shalabay, Victoria V., 13

Shuvalov, Andrei A., ON

Skaptsov, Alexander A., OT, 14, 15, 16

Skibina, Yulia S., OM, ON, OT

Skrypnik, Alexei $\mathrm{V}_{\text {., }} \mathrm{OC}$

Smirnov, Sergey N., OB, OC

Snimshchikova, I., 04

Stelmashchuk, O., 04

Stepanovich, E. YU., OJ

Stiukhina, Elena S., OV, OW

Sukhorukov, Gleb B., 00

Sviridov, A. P., 1C

Terentyuk, Georgy S., OQ

Terziev, Ivan, 02

Tikhomirova, Elena I., OE

Timoshina, Polina A., 10

Torbin, S. O., OA

Tsareva, O. E., OA

Tuchin, Valery $\mathrm{V} ., 0 \mathrm{~J}, 0 \mathrm{OQ}, \mathrm{OU}, \mathrm{OV}, \mathrm{OW}, 10$

Tuchina, Daria K., 10

Tuchina, E. S., OF

Tychina, S. A., OX

Ulianova, Onega $\vee .$, OD
Ulyanov, Sergey S., OD

Ulyanov, Vladimir YU., OE

Ushakova, O. V., OF, OG, 1B

Ustalkov, Sergey O., 14, 16

Vakaraeva, Malika M., OE

Vanzha, Ekaterina, OL

Velichko, Elena, $\mathrm{OH}$

Velikov, Vladimir A., 17

Vinokurov, A., 04

Vladimirov, Borislav, 02

Volkov, M. V., 07

Wagner, Christian, 05, 06

Yuvchenko, S. A., 19

Zabenkov, I. V., OA

Zakharevich, Andrey M., OM, 13, 15

Zayarsky, Dmitry A., OE

Zaytsev, Sergey S., OD

Zenkin, Nikita S., OK

Zharkikh, E. V., 07

Zherebtsov, E. A., 04, 07, 08

Zherebtsova, A. I., 04, 08

Zimnyakov, D. A., 18, 19, 1A, 1B, 1C

Zinchenko, Ekaterina M., 10 


\section{Conference Committee}

Conference Chairs

Elina A. Genina, (Secretary) Saratov National Research State University, (Russian Federation) and National Research Tomsk State University (Russian Federation)

Valery V. Tuchin, Saratov National Research State University (Russian Federation) and National Research Tomsk State University, (Russian Federation) and Institute of Precision Mechanics and Control, RAS (Russian Federation)

Conference Program Committee

Victor N. Bagratashvili, Institute of Laser and Information Technology, RAS (Russian Federation)

Alexey N. Bashkatov Saratov National Research State University (Russian Federation), National Research Tomsk State University (Russian Federation)

Walter Blondel, Université de Lorraine (France)

Alexander V. Bykov, University of Oulu (Finland)

Wei Chen, University of Central Oklahoma (United States)

Kishan Dholakia, University of St. Andrews (United Kingdom)

Maria Farsari, IESL-FORTH (Greece)

Paul M. W. French, Imperial College of London (United Kingdom)

James G. Fujimoto, Massachussets Institute of Technology (United States)

Steven L. Jacques, Oregon Health \& Science University (United States)

Vyacheslav Kalchenko, Weizmann Institute of Science (Israel)

Sean J. Kirkpatrick, Michigan Technological University (United States)

Jürgen M. Lademann, Charité Universitätsmedizin Berlin (Germany)

Kirill V. Larin, University of Houston (United States)

Martin Leahy, National University of Ireland, Galway (Ireland), and Royal College of Surgeons in Ireland (Ireland)

Qingming Luo, Huazhong University of Science and Technology (China)

Risto Myllylä, University of Oulu (Finland)

Alexey P. Popov, University of Oulu (Finland)

Juergen Popp, Leibniz-Institute für Photonische Technologien e.V. (Germany)

Alexander V. Priezzhev, M.V. Lomonosov Moscow State University (Russian Federation)

Lihong Wang, Washington University in St. Louis (United States) 
Ruikang K. Wang, University of Washington (United States)

Dan Zhu, Huazhong University of Science and Technology (China)

Session Chairs

1 Plenary Session I

Valery V. Tuchin, Saratov National Research State University

(Russian Federation) and National Research Tomsk State University, (Russian Federation) and Institute of Precision Mechanics and Control, RAS (Russian Federation)

2 Plenary Session II

Alexander V. Priezzhev, M.V. Lomonosov Moscow State University (Russian Federation)

3 Plenary Session III

Ekaterina I. Galanzha, University of Arkansas for Medical Science (United States)

$4 \quad$ Plenary Session Internet Biophotonics IV

Valery V. Tuchin, Saratov National Research State University (Russian Federation) and National Research Tomsk State University, (Russian Federation) and Institute of Precision Mechanics and Control, RAS (Russian Federation)

5 Plenary Session $V$

Kirill V. Larin, University of Houston (United States) 


\section{Introduction}

The 4th International Symposium on Optics and Biophotonics (Saratov Fall Meeting SFM 16) was held in Saratov, Russian Federation, 27-30 September 2016 with over 500 participants from the Russian Federation, United States, Canada, Europe, Asia, and South Pacific countries. It covered a wide range of modern problems of fundamental and applied optics, laser physics, photonics, and biomedical optics.

This volume includes selected papers of the following conferences and workshops organized in the framework of the symposium:

Optical Technologies in Biophysics and Medicine XVIII

Elina A. Genina, Igor Meglinski, and Valery V. Tuchin (Chairs)

Spectroscopy and Molecular Modeling XVII

Lev M. Babkov and Kirill $\vee$. Berezin (Chairs)

Nanobiophotonics XII

Nikolai G. Khlebtsov (Chair)

Microscopic and Low-Coherence Methods in Biomedical and Non-Biomedical Applications IX

Kirill V. Larin (Chair)

Internet Biophotonics IX

Alexey N. Bashkatov, Ivan V. Fedosov, and Valery V. Tuchin (Chairs)

Low-dimensional Structures VI

Olga Glukhova (Chair)

Biomedical Spectroscopy III

Vyacheslav I. Kochubey and Alexander B. Pravdin (Chairs)

Advanced Polarization Technologies in Biomedicine and Material Science III

Igor V. Meglinski and Dmitry A. Zimnyakov (Chairs)

The main attention was paid to the discussion of fundamentals and general approaches of description of coherent, low-coherent, polarized, spatially and temporally modulated light interactions with inhomogeneous absorbing media, low-dimensional structures, tissues, and tissue phantoms. Optical properties of various tissues measured in-vitro, ex-vivo, and in-vivo as well as optical biopsy techniques were under consideration. Static and dynamic light scattering in 
tissues, Doppler, photo-acoustic and photo-thermal laser-tissue interactions, lightinduced mechanical stress, and photodynamic effects also were considered. On this basis the variety of laser and optical technologies for medical diagnostics, therapy, surgery, and light dosimetry, as well as for spectroscopy of random and ordered media, were presented.

SFM16 was organized into morning plenary sessions, afternoon lectures and oral sessions, and then evening poster presentations and Internet discussion. The attendees with a great interest to plenary lectures delivered by leading experts in urgent fields of optical and laser life, and were discussed by the audience.

Plenary and invited lectures, oral, and poster presentations covered a wide area of tissue optics, spectroscopy and imaging, controlling of optical properties of tissues, as well as biophysical and photo-chemical aspects of photo- and laser therapy.

In the framework of the symposium, a competition for the Best Student Poster Award was organized supported by the SPIE FOCUS Program. Two of the winning papers are included in this volume, 1033603 and 1033604.

The traditional specific feature of Saratov Fall Meetings was the Internet Session and one-day online discussion. In 2016, this Internet session included 5 plenary lectures, 10 invited lectures, and 29 oral presentations.

A full list of the papers by the Internet session participants (who hailed from the United States, the Russian Federation, Denmark, Germany, Netherland, Ireland, Italy, Finland, Poland, Israel, China, and others), located at the meeting website: $\mathrm{http}: / / s f m . e v e n t r y . o r g / s y m p o s i u m 2016 / i n t e r n e t$, were available during the meeting and will be available for a whole year until the next meeting.

It was great pleasure and privilege for the editors to thank all authors for their contributions to the symposium. Special thanks to the plenary, invited, and Internet lecturers for their exciting presentations.

The organizers of SFM16 are grateful to all the sponsoring organizations and programs that efficiently supported this meeting, especially to:

The Optical Society;

Russian Foundation for Basic Research (grant №1 6-02-20591, 2016);

SPE "Nanostructed Glass Technology" Ltd. (Russian Federation);

RME "INJECT" LLC (Russian Federation);

COST Action, BM1205 (European Cooperation in Science and Technology);

Grant № 14.250.31.0004 of Government of the Russian Federation; Presidential grant of the Russian Federation for Leading Science Schools № 7898.2016.2; 


$$
\begin{aligned}
& \text { Russian Technology Platforms "The Medicine of the Future" } \\
& \text { and "Photonics" (Russian Federation); } \\
& \text { European Technology Platform "Photonics21" (Russian Federation); } \\
& \text { and EPIC - European Photonics Industry Consortium. }
\end{aligned}
$$

A full list of conference organizers can be found on page $x v$ of this Front Matter.

Elina A. Genina Valery V. Tuchin 
Proc. of SPIE Vol. 10336 1033601-14 Downloaded From: https://www.spiedigitallibrary.org/conference-proceedings-of-spie on 26 Apr 2023
Terms of Use: https://www.spiedigitallibrary.org/terms-of-use 


\section{Organizers}

Saratov National Research State University (Russian Federation)

Research-Educational Institute of Optics and Biophotonics at Saratov National Research State University (Russian Federation)

International Research-Educational Center of Optical Technologies for Industry and Medicine "Photonics" at Saratov National Research State University

(Russian Federation)

Institute of Biochemistry and Physiology of Plants and Microorganisms

(Russian Federation)

Institute of Precision Mechanics and Control (Russian Federation)

V.I. Razumovsky Saratov State Medical University (Russian Federation)

National Research Tomsk State University (Russian Federation)

Volga Region Center of New Information Technologies (Russian Federation)

University of Oulu (Finland)

SPIE Student Chapter of Saratov National Research State University

(Russian Federation)

OSA Student Chapter of Saratov National Research State University

(Russian Federation)

Saratov/Penza IEEE (Russian Federation) 
Proc. of SPIE Vol. 10336 1033601-16 Downloaded From: https://www.spiedigitallibrary.org/conference-proceedings-of-spie on 26 Apr 2023
Terms of Use: https://www.spiedigitallibrary.org/terms-of-use 